\title{
CIRCULAR ECONOMY - FROM WASTE TO RESOURCE: 7RS INNOVATIVE PRACTICES IN AMSTERDAM. TECHNOLOGIE "DIE NOG IN DE KINDERSCHOENEN STAAN"
}

\author{
Barbara Maisonnave Arisi ${ }^{1}$
}

\section{INTRODUCTION ${ }^{2}$}

The European Commission is predicating all governments of its member countries to move from what is now labeled as a linear economy (four stages of a life resource material/product, from extraction to disposal, or from "cradle to grave") to treating waste as food (or from "cradle-to-cradle", as McDonough \& Braungart (2002) called it, into adopting a 'circular economy package ${ }^{3}$ (where the resource material/products would go back into the cycle of production after its first lifespan - see graphic 1).

In order to achieve this circular economy model, according to EC's documents, legislative proposals on waste would have to be revised in order to make possible and to impulse Europe's transition towards a circular economy. Before I started studying the documents, I thought that the movement was driven by an environmental agenda and necessity in face of the dilapidation of nature that I have observed in loco, being myself an anthropologist that carries out research with indigenous people in the Amazon forest since 2006. I was surprised when I realised that most of the EU documents justify this move because it will "boost global competitiveness, foster sustainable economic growth and generate new jobs" in Europe (European Commission, 2015).

\footnotetext{
${ }^{1}$ Universidade Federal de Santa Catarina, Brasil. Email: barbara.arisi@gmail.com ORCID id: https://orcid.org/0000-0001-7560-9636

This study was financed in part by the Coordenação de Aperfeiçoamento de Pessoal de Nível Superior Brasil (CAPES) - Finance Code 001. I would like to thank CAPES and Prof. Dr. Carmen Rial for her support in this research and Dr Roy Gigengack for the opportunity to discuss about the paper with him and his students in the Amsterdam University College on November 2020.

${ }^{2}$ About the title: It alludes to this Dutch expression, "staat nog in de kinderschoenen", which means "that are still walking in children's shoes". So, technologies that are in their children shoes are "technologies that are still being developed".

3 I would like to call into attention on the words deployed and spread by these fundamental documents, as it is interesting to reflect on these terms from an exotic or anthropological critic perspective which means never taken them for granted.
} 
The Circular Economy, a win-win situation: Savings of $€ 600$ billion for EU businesses, equivalent to $8 \%$ of their annual turnover Creation of 580,000 jobs; Reduction of EU carbon emissions by 450 million tonnes by 2030 (European Commission, 2015).

The people who wrote these documents were dedicated in explaining why it is important to move towards a circular economy and how they envisaged to heat up an economy that became moribund after the period that some economists named "the crisis of 2008", as the excerpt states:

The circular economy offers an opportunity to reinvent our [European] economy, making it more sustainable and competitive. This will bring benefits for European businesses, industries, and citizens alike. With this new plan to make Europe's economy cleaner and more competitive, the Commission is delivering ambitious measures to cut resource use, reduce waste and boost recycling (European Commission, 2015).

In 2014, when the first "package" was presented by the European Commission, it targeted waste management under the title "Towards a circular economy: a zero waste program for Europe". Within one year, it evolved and some EU communications were released pointing at new areas of "opportunities" such as: sustainable buildings, "green jobs" and creating a "Green Action Plan" for Small and Medium-size Enterprises calling the attention of all member countries to take advantage in the swift mobility towards a circular economy. "The Circular Economy is defined by the European Commission as minimising the generation of waste and maintaining the value of products, materials and resources for as long as possible" (Stegman et alli, 2020).

Concerning waste, the EC planners set goals and deadlines that they themselves consider as ambitious. In municipal waste management, for example, the goal is to achieve recycling $65 \%$ of all collected waste by 2030 and recycling $75 \%$ of packaging waste by the same year. The landfill target was set to a maximum of $10 \%$ of municipal waste and a complete ban of the landfilling of separately collected waste and promoting economic instruments to discourage the countries that have not a ban already of landfilling (as it is already the case in The Netherlands). They launched academic support calls under Horizon 2020 to try to attract academic experts to create a common ground to calculate methods for recycling rates throughout the EU. Another dreamed target presented by EC aims to develop concrete measures to promote re-use and to stimulate industrial symbiosis that the document explain as being turning one industry's 
by-product into another industry's raw material. And, finally, to create economic incentives for producers to develop what they call "greener products" on the market and to support recovery and recycling schemes (especially, as they clarify, for packaging, batteries, vehicles and electronic equipments).

In 2015, a public consultation was open from May to August and several debates with finance specialists were organised to take place throughout Europe. In 2016, a seminar organised by the EU titled "Making it happen" took place in Brussels, Belgium. Environmentalists, activists, practitioners and academics have pointed out the several difficulties in achieving Circular Business Models (CBMs):

Most of the literature argues that proactive cooperation between the business network actors through coordinated BM [business models'] innovations is essential to close product and material loops. However, most sectors and industries, such as textile, electronics, food, or mobility, have global, highly fragmented, and dispersed supply chains (Hofmann 2019: 370).

So it means that it is difficult to change the flow of resources and to achieve circularity. Since 2017, some scholars considered that the concept of "circular economy" is not sufficient to achieve sustainable economic configuration. By criticising the obsolescence of electronic equipments and defending a political economy that would be inclusive and participatory, they propose that it is necessary to think and to act in the direction of achieving a "circular society", one that could provide more space for "communality and social innovativeness" (Research Group Obsolescence, 2019). In this concept, not only the focus lay in the economical circuits and value-chains, but it takes into deeper consideration the people and their social relationships. 


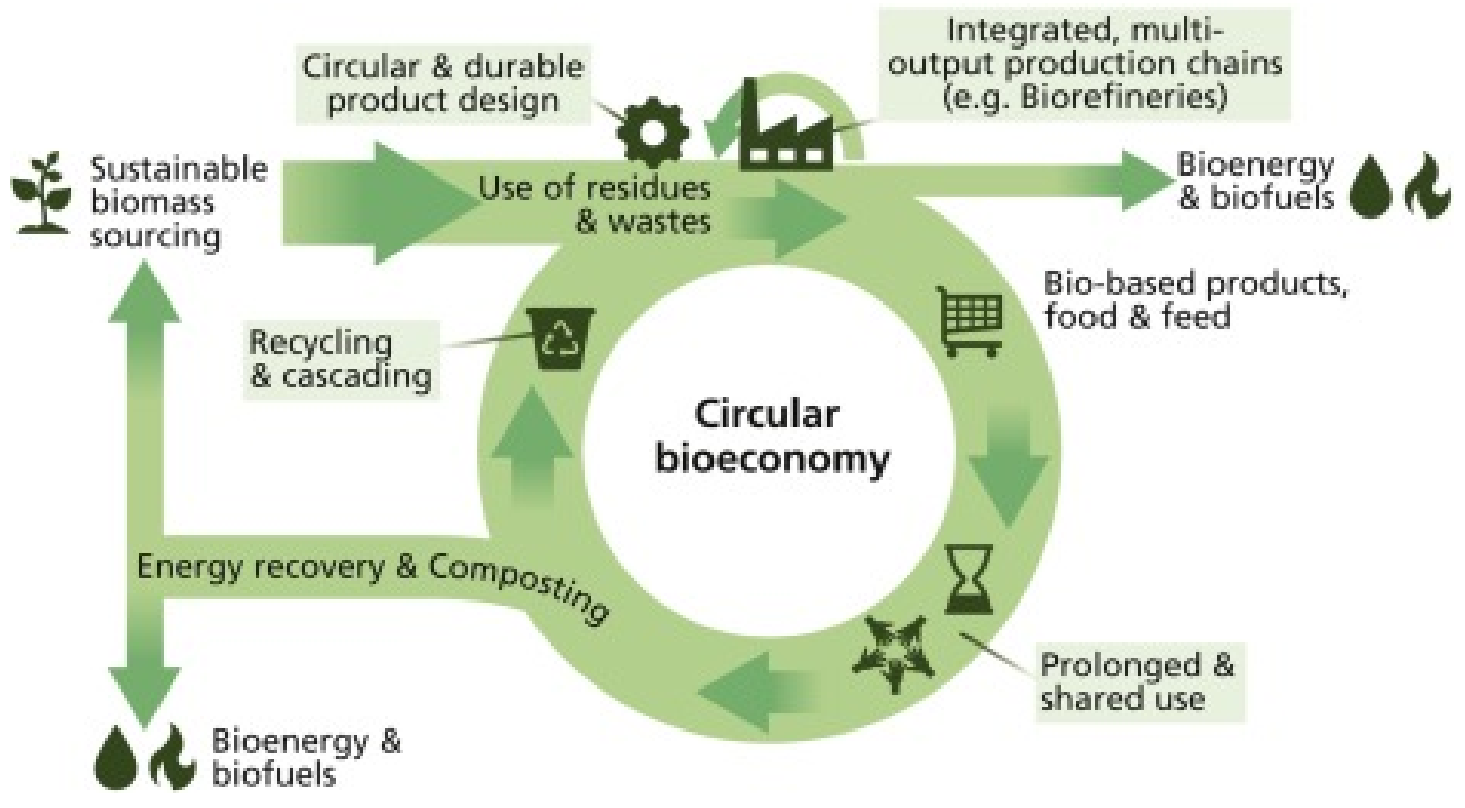

Graphic 1 (Stegman et alli 2020)

Some other scholars wrote a new proposition that the EU should focus on a "circular bioeconomy." In a "circular bioeconomy", the flow of resources/materials would be like this image tries to resume (Stegman et alli, 2020):

They pay attention to the biomass (organic residue in industrial scale) and they define it like this:

The circular bioeconomy focuses on the sustainable, resource-efficient valorization of biomass in integrated, multi-output production chains (e.g. biorefineries) while also making use of residues and wastes and optimizing the value of biomass over time via cascading. Such an optimization can focus on economic, environmental or social aspects and ideally considers all three pillars of sustainability ${ }^{4}$. The cascading steps aim at retaining the resource quality by adhering to the bio-based value pyramid and the waste hierarchy where possible and adequate. (Stegman et alli, 2020)

\footnotetext{
${ }^{4}$ The three pillars of sustainability would be: society, economy and environment, and the concept was probably first developed by Barbier (Purvis, Mao \& Robinson 2019).
} 
In March 2020, the European Commission launched another communication document to the European Parliament called "A new circular Economy Action Plan". Its conclusion is the following:

The transition to the circular economy will be systemic, deep and transformative, in the EU and beyond. It will be disruptive at times, so it has to be fair. It will require an alignment and cooperation of all stakeholders at all levels - EU, national, regional and local, and international. Therefore, the Commission invites EU institutions and bodies to endorse this Action Plan and actively contribute to its implementation, and encourages Member States to adopt or update their national circular economy strategies, plans and measures in the light of its ambition. Furthermore, the Commission will recommend including the circular economy among the topics for discussion on the future of Europe and a regular theme of citizens, dialogues (European Commission, 2020).

This research is devoted to follow up what is happening in this turning point for the world economy, when the biggest world market of the European Union looks for ways to change dramatically its economy. The debate is taking place and there not so many anthropologists and sociologists engaged on it yet. It is fundamental that we, as social scientists, participate in the interdisciplinary efforts it requires, broadening our conceptual frame work and looking for ways to contribute, in order that it is not done just from an economical perspective, but that it takes into account the local practitioners. That is what I will present in the following section.

\section{Local knowledge for local solutions}

In this paper, I intent to examine some practices in the Netherlands that we could see under the light of "circular bioeconomy" concerning organic and plastic waste. Some of the innovation experiences I present here reach the goal of being local solutions in waste management, like the "Wormenhotels", for example. This is one of the goals of circular bioeconomy: to develop local solutions to close loops of materials/resources ${ }^{5}$ in order not to generate waste but to keep the materials circulating to stimulate life circles. "Shortening and downsizing value circles by regionalizing the value creation and delivery infrastructures is one gradual strategy to diminish complexity" (Hofmann 2019: 371).

Some of these practices were developed much before the label/the concept was deployed as European policy. They are already implemented in The Netherlands and

\footnotetext{
${ }^{5}$ A close loop is a key topic for circular economy, and it means that the outputs have to take into consideration the input so that the loss of resource is minimum.
} 
they accomplish one of the 7Rs: Rethink, Refuse/Reduce, Reuse/Rehome/Repurpose, Recycle, Recreate, Repair and Rot. I use the reference to the 7 Rs as a way to classify the circular experiences I collected since I started studying the subject from an anthropological perspective in 2016.

For the readers that had never heard about the 7Rs, let's explain about it. In the early years of environmentalism, some campaigns presented a circular green thought divided in 3Rs of actions: Reuse, Reduce and Recycle. Later, they became 5Rs: Rethink, Reduce, Reuse, Recycle and Recreate. Sometimes in place of Recreate (for industrialised objects) you would find it the R for Rot (for organic waste). Recently, designers introduced a sixth $\mathrm{R}$ that is very relevant for circular economy: to Repair. I prefer to use the 7 Rs as I like to differentiate Recreate from Rot. I will use the 7Rs as a classification for these experiences that we can consider as innovative practices.

Finally, I would like to inspire the readers by bringing the role of utopia and imagination as important forces that can animate social and ecological transformation towards life on the planet.

1) Rethink (Living Laboratories or Living Labs),

2) Refuse/Reduce (Plastic Soup Foundation; Social Experiment 100-100-100),

3) Reuse/Rehome/Repurpose (Weggeefwinkels),

4) Recycle (Precious Plastic)

5) Recreate (Precious Plastic, again)

6) Repair (Café Repair)

7) Rot (Wormenhotels)

1R) Rethink: Living Labs

In Amsterdam, there are Living Labs that experiment with sustainable projects. One is placed in the square across the Vrije Universiteit Amsterdam main building, in De Boelelaan, where I work (before the Corona crisis!). It is located in Zuid, a neighbourhood full of office buildings with skyscrapers (above tilts like all Amsterdam buildings). Last year, a Green Living Lab was created to experiment with organic waste. For example, one experiment called "biomelier" was built in the Green Living Lab by volunteers, some of them psychology students that wanted to test how nature influence 
the urban dwellers mental health. The biomelier was designed by Rowin Snijder (I will write about him as well in the Rot session/Wormenhotels). He created an organic compost place and its heat (with wooden chips to compose the compost layers) was used to warm up the floor of the kind of dome, a tent they built in a icosahedron shape, copying the structure of the natural form of the Carbon 60. In 2020, it hosts a "research laboratory" for the university's environmental psychologists to carry on a research about an eventual link between nature and mental health and also it served as a venue for small cultural events. Around the dome, they planted an organic garden and, what now is a novelty in The Netherlands, a "food forest" (voedselbos, in Dutch). In Brazil, there is a long permaculture tradition, but it is still incipient in The Netherlands ${ }^{6}$. In the Green Living Lab, they use the organic compost warmth to heat up the floor of the dome tent with the "biomelier". As they explain in the site about the project:

A biomelier is a large heap of composting woodchips with a water pipe placed in the centre. Bacteria produce heat during the composting process $\&$ this heat is captured by water inside the water pipe. This warm water circulates through the biomelier \& can be transported to a heat exchanger (warmtewisselaar) or used directly to heat a space. A biomelier can also be used to heat water for showers \& to wash clothes. (Green Living Lab, 2020)

This Green Living Lab has an inspiration that is: "learning from nature for a healthy world". Its creators think that the "living labs"empowers young people to feel optimistic about their ability to make a positive impact in the world" (Green Living Lab, 2020).

\footnotetext{
6 To learn more about the "food forest"projects in The Netherlands, research online for the name Wouter Van Eck, pioneer of the "food forest (voedselbos, in Dutch), an inspiration Van Eck got from the people from Ghana.
} 


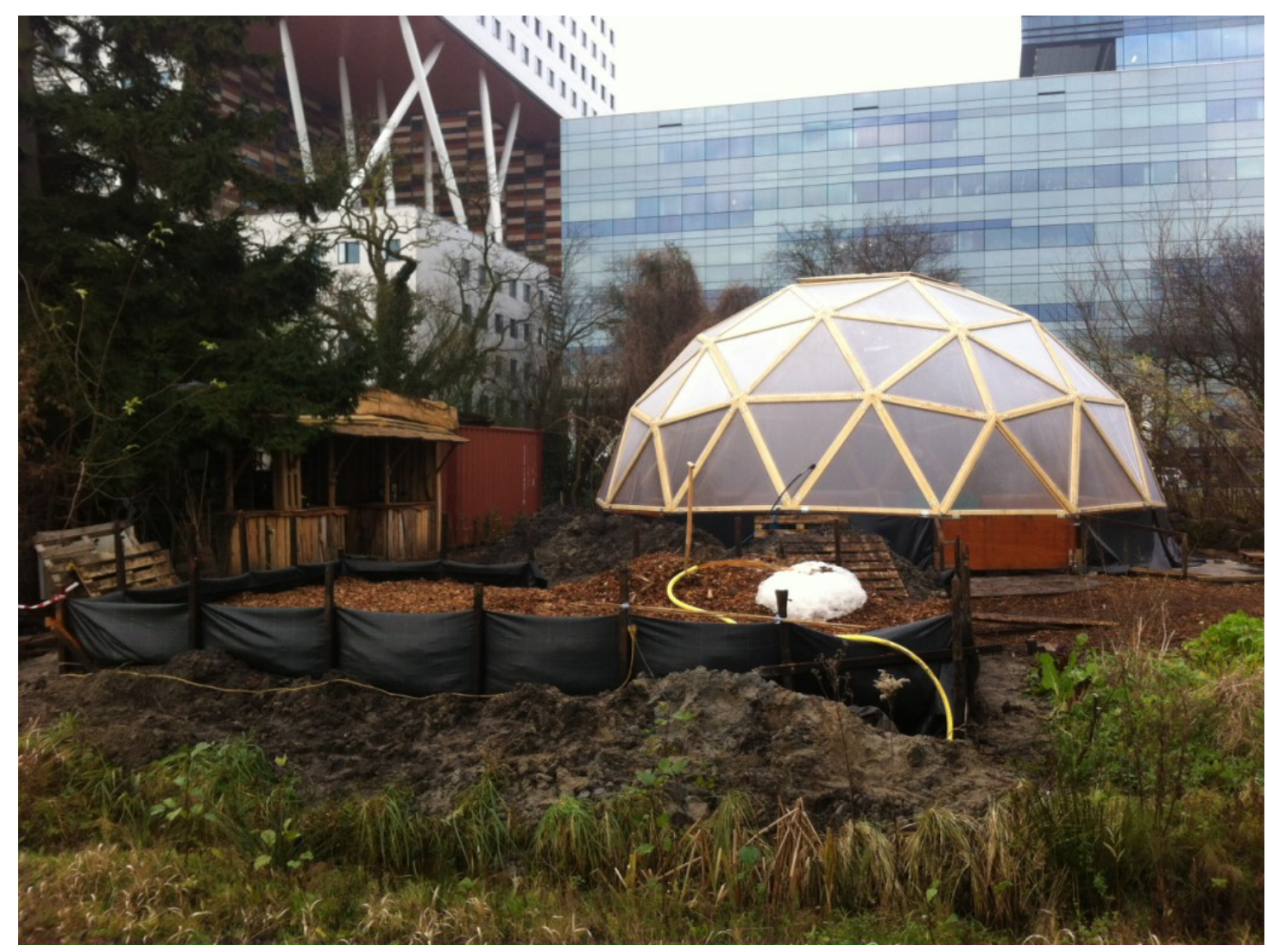

Biomelier and dome in the Green Living Lab, picture available online:

http://greenlivinglab.org/our-programmes/programme-lab/heat-from-compostintroducing-the-biomeiler/

Amsterdam has some other sustainability laboratories. One called Mediamatic, created in 1983, is dedicated to study the ways we can work with micaelia (funghi) as an isolator material, for example, or how can we collect urine from public toilets to use in urban gardening, to offer another example. Mediamatic is located close to the Centraal Station, serving also as a propaganda lab. That is how they define their mission:

In Mediamatic, we are always looking for new developments in society. We are interested in how art, design and science merge and how we can use this to experiment with new (living) materials. We challenge the senses and tackle perceptions regarding food, waste and unconventional materials such as piss, bacteria and fungi (Mediamatic, 2020)

Not far away from Mediamatic, there is another Living Lab, neighbour to the Nemo and to the Maritime musea. They they try to develop the reuse of pee to capture phosphorus from the urine of its visitors. There was developed as an experiment some public toilets designed specially to capture pee. The urine would then be filtered, the urine was purified and the phosphorus captured was used in the organic garden from which the visitors can also pick up some green products, like tomatoes. 
In August 2020, the Mediamatic experiment was used by the municipality of Amsterdam that tries to combat "wild peeing", 12 urinals were installed in the city center, close to the Red Light District, where many bars and night life are located.

The initiative is an extension of previous Dutch trials to farm fertiliser from toilet visits. Arts centre Mediamatic has cleaned and used urine from five urinals as part of the 'pure gold' display, while urine was also temporarily collected on King's Day by the Dutch water board in 2016. The GreenPee is thought to be the first attempt to make this recycling a permanent fixture of city life. (DutchNews, 2020)

The Living laboratories offer an opportunity for the municipalities to experiment, to test, to try something in a smaller scale and if they do work, the municipality can adapt to try our in the city. The Living Labs are built as promoters of inspiration for innovation that can contribute to urban sustainable solutions. The Marineterrein $^{7}$ (old harbour area) in Amsterdam is now home for more living labs that are testing feasibility of projects in the urban space. The Living Labs are spaces where we, as society, can rethink about our own behaviour and our practices. We can experiment and to think about ordinary movements from our lives, like the food we throw away or our own urine in a very different way.

\section{R) Refuse / Reduce}

\section{Plastic Soup Foundation - campaigning for a world ban of microbeads Social Experiment 100-100-100}

Another example of Rethink that took the more extreme direction of Refuse is developed by the NGO Plastic Soup Foundation. In 2016, I went to visit their office in Amsterdam. This activist group makes a local and a global impact in what a Rabobank manager named as the "anti plastic-sentiment" (Kamminga-Nti, 2020). It grew a lot in the last years. From when I started my research in 2016 until now, the term "Plastic Soup" became a local term, and the NGO has spread its word, via media, via campaign posters in bus stops and it became a kind of simple slogan that impact the way people think about plastic. The slogan of the NGO is: "No plastic in our water or our bodies" (Plastic Soup Foundation, 2020).

\footnotetext{
${ }^{7}$ To learn more about it, check: www.living-lab.nl/projects
} 
The term "plastic soup" 8 is a metaphor used by scientists and campaigners to refer to the plastic litter existing in the oceans, mainly constituted of microplastic ${ }^{9}$, nanoplastics and plasticizers whose impacts on human and other animal and vegetal beings are still understudied by natural scientists (Heather, 2014; Liborian, 2015; Van Franeker \& Kühn, 2019). The concern started with marine researchers and environmentalists, and it became largely publicised with images of sand beaches covered in litter spread all over in the internet. Last year, Van Franeker \& Kühn (2019) published their results from a research about the amount of plastic found inside the guts of a bird. The North Sea bird they studied is called 'petrel', in English ('stormvogel', in Dutch). The researchers concluded that there were in average 24 pieces of plastic per bird - a total of 0,26 grams. In order to give us a way to better understand it, this amount would be equivalent to one bread roll size for an adult human being.

Other scientific research shows that in fact when researchers turn their attention to marine environments the amount of plastic litter found is real and yet impossible to measure (a lot might be in the bottom of the ocean, and the fact is nobody really knows where all the amount of used plastic goes to ${ }^{10}$. Eriksen et all (2014) estimated that there were more than 5 trillion pieces that would amount to 250,000 tons of plastic afloat at sea.

\begin{abstract}
Once released into the environment, microplastic materials are expected to persist for centuries before becoming fully decomposed and reentering normal biogeochemical cycles. Due to extremely slow decomposition kinetics of the macromolecules in plastic, it has been postulated that all plastic that has ever been released into the environment still exists today. (Heather 2014: 8)
\end{abstract}

\footnotetext{
${ }^{8}$ Some criticise the term "soup" and propose that we should use instead "plastic smog" (Liborian 2015) as most of the small pieces are invisible to human eyes. Still, the term Plastic Soup has being more used nowadays and everybody understand the word better than "smog", more vague than soup. Liborion proposes the word "miasma" to refer to the kind of plastic and plasticizer pollution we are all becoming immersed in (and also becoming made of, as researchers shows that our bodies also contain plastic) (Heather 2014). Liborion believes the era "miasma" is potential for action and it is a theory model that aims at preventing diseases. She is following a proposal made by Bloom, a Public Health employee that in 1965 wrote about sanitarians that, in the XIX century, could reduce mortality through prevention and community interventions, without isolating diagnoses and assigning treatments. According to Liborion, the word "miasma" could be used to refer to what plasticizers could do to our body and our health, as medic doctors still do not have enough research to name what kind of harm (if any) the plasticizers represent.

9 'Microplastics' are particulates made of plastic material less than $5 \mathrm{~mm}$ in size that make up the microsized fraction of plastic marine litter. Microplastics represent an emerging topic in pollution research and policy making. Many organisations are currently seeking to identify the various potential sources of microplastic pollution in order to guide decision-making on mitigative actions (Heather 2014). Nanoplastic are particles that result from the degradation of plastic, they are than $1 \mu \mathrm{m}$ (or $1000 \mathrm{~nm}$ ) or smaller than $100 \mathrm{~nm}$ in size.

${ }^{10}$ In many countries, the water sewage will go untreated to watersheds; in Europe, it will be also used in agriculture, bringing the nano particules to open waterways (Heather 2014: 9).
} 
In Amsterdam, for my fieldwork, I went to visit the Plastic Soup Foundation small office located in the Westerpark where back then 12 people worked. Since 2012, the NGO members try to influence decision makers to ban microplastics use in corporations like the giant Unilever and the government of the United States. So far, they won already some battles with communication campaigns aiming to eliminate plastic microbeads from the formula of cosmetica and toothpaste, for example. They did so by developing an app where a consumer could check if the product offered in a supermarket contained or not microbeads in its formula. That campaign was titled "Beat the Microbead". They also proposed and developed a positive approach towards certification, by labelling products that do not contains microplastics with a design that informs "Zero Plastic Inside". They based their arguments on research findings made public in 2015 by the United Nations Environment Programme (UNEP) that recommended a precautionary approach towards microplastic management, the beads have been used in the last 50 years by personal care and cosmetics industry (Heather 2014). The Netherlands, Austria, Luxemburg, Belgium and Sweden had issued a call to ban the microplastics in industries. Plastic Soup Foundation is an example of how to Rethink about plastic, or better written, a way how to Refuse plastic.

\section{Social experiment 100-100-100}

Another innovative project developed in order to reduce solid residue was a social experiment that took place in more than a 100 municipalities in The Netherlands called 100-100-100 (one hundred households that would try to live 100 days generating $100 \%$ zero waste). Created by Rova, a solid residue management company based in Zwolle, it developed a platform online where volunteers participated in a digital "community" where they could share their experiences and tips in online chat groups. They helped each other in trying to find solutions not to generate waste or how to separate better their paper, plastic, metal, cloth and other solid residue, avoiding to use the bin that is called in Dutch "restafval" (the left over rubbish, the rest in a more literally translation into English). The experiment site is in Dutch language and the URL link is still available: https://www.100-100-100.nl . They inform that in 2020 Antwerp, Belgium region neighbour to The Netherlands, is going to start a new edition with 656 families registered to participate on it. 
The results of the experiment were quite positive with some people being able to generate $90 \%$ less solid residue waste than previously they used to. Unfortunately, the positive lasting impact in the behaviour of its participants can not be taken for granted. In 2020, I supervised the BA dissertation research of Brander. She researched with the participants of the social experiment in Amstelveen, municipality neighbour to Amsterdam and part of the same urban region and concluded the following:

\begin{abstract}
Although the project has been experienced very positively by the participants, it cannot be said that it has had much concrete influence on their behaviour. Some specific examples emerged, especially tips from other participants, which are still being implemented in their daily lives. Since the participants (at least the ones I spoke to) are not a good cross-section of the Amstelveen population, it cannot be said whether a larger 100-100-100 project would lead to spillover or behavioural change. (Brander 2020: 12)
\end{abstract}

Nevertheless, many people could profit from the learning opportunity, at least a big group of people have experienced (hands-on) what is necessary if we really want to reduce producing waste. Another positive aspect of the 100-100-100 experiment was the friendly approach and the communication campaign deployed. I interview in 2016 one of the creators of the campaign, communication manager Eric Van Cuyp, and he explained me that usually campaigns to bring awareness about waste reduction have a bossy approach, lecturing on how people should do things, to separate their waste, how to dispose, where to bring, threatening with fines the ones who don't do it. In 2014, a communication specialist decided to develop a kind of social experiment and transform it in a social media experience. In a world where more and people share pictures of their daily food dishes via Instagram and many people keep even family relationships online, the idea of creating a community bonding via internet worked out fine. The Zero Waste initiatives are becoming more visible and this experiment helped to bring awareness to general public in The Netherlands as a way to Rethink about discard and to Refuse generating waste.

\title{
3) Reuse/Rehome/Repurpose
}

\section{"Weggeefwinkels" in Dutch, "Swap shop" in English}

The first time I went to a "swap shop"was in United Kingdom in 2010, the concept of a shop where you could take things (utensils, clothes, etc) instead of buying them paying for them with money was new for me. As a $\mathrm{PhD}$ candidate student living 
from my scholarship from CAPES (Brazilian higher education agency), I went to check it out and came back home with a lot of stuff that made my life better like a study lamp and a winter coat. It was in Oxford, city where Oxfam and so many other charities' shops with second hand clothes were created. The concept of "swap shop" was different than other shops, it was not necessary to bring money, you could go empty handed and leave with what other people donated, the focus was on circulation of goods, in making a sustainable positive impact against consumerism. I mentioned this personal story here even though it is an experience from England, outside the area focus of this article, just to bring a short field work note and part of my personal experience as an anthropologist. That is how I came to learn the concept of "weggeefwinkel", called "swap shop" in English.

I also mentioned it because this article is about The Netherlands but I am writing it in English language and I believe there is something interesting to observe in the two different words used in the two countries and their respective different languages, even though Dutch and English share some of the same Saxon linguistic origins. While in English we could translate "swap shop" for a shop where you can exchange (to swap) your objects, in the Dutch language the term is not a translation, it has another meaning, it is called "weggeefwinkel", where "weggef" comes from "weg te geven" which means 'to give away', and "winkel" means 'shop'. In Dutch, the meaning of something that has been donated or given away is much more clear, it explains that it is a different kind of shop where you can expect to get 'given away' ${ }^{11}$ stuff.

Another interesting difference lays in how the shops are organised in both countries. While in Oxford it was organised in a communitarian center and some churches, in Amsterdam and other cities in The Netherlands, the occupied houses (called "squats") are the places where most of the "weggeefwinkels" are organised. In The Netherlands the "weggeefwinkels" were (and many still are) organised and created by "squatters", so they have this self-organisation political background. I went several times to one located in the oldest still running squat in Amsterdam called "Joe's Garage $^{12 ",}$ located in Pretoriustraat. Since 2005, Joe's Garage is a political social cultural center that runs thanks to volunteers.

\footnotetext{
${ }^{11}$ The debate about "giving" being the starting point of obligations in social relations and the reciprocity theory, from our dear anthropologist ancestor Marcel Mauss, will not be brought in this paper, but an observation could not be missed.

12 The name is homage to Frank Zappa's rock opera album.
} 
Joe's Garage's "weggeefwinkel" opens on Saturdays afternoons, the "shop" events were organised by some of the women that lived in the squat and the other women (mainly) who came to collect and to take most of the clothes were old ladies from the neighbourhood. It offered a fashion contrast to see most of the squatter volunteers dressed in black punk clothes and the ladies from the neighbourhood with embroidered head veils covering their hairs helping each other to fold clothes and trying out some coats. The "weggeefwinkels" are a kind of social experiment that already have traveled worldwide. In the neighbourhood of Florianópolis, in Brazil, where I lived, a communitarian closet was created three years ago with the same principle of the Dutch "weggeefwinkels": you are free to take whatever you need or want from the closet without necessity of paying for it.

Some of the organisers of the "weggeefwinkels" (that I could better now translate for "give away shops") consider that they do political work against consumerism and, at the same time, they help people to have access to clothes, utensils or goods. One organiser of the Joe's Garage "weggeefwinkel" told me that she believes that the "weggeefwinkels" help the environment as well by participating in the circulation of goods. Most of the people I talked to in more than five different "weggeefwinkels" say that their main goal was to fight consumerism. When asked if they believed the shop could have also an environmental impact, all the organisers answered me that they were also helping the planet and the nature from stopping use of water and many other materials like metal and plastic from even being produced, so by reducing consume and circulating clothes and utensils that they were helping to create more sustainable lives. 


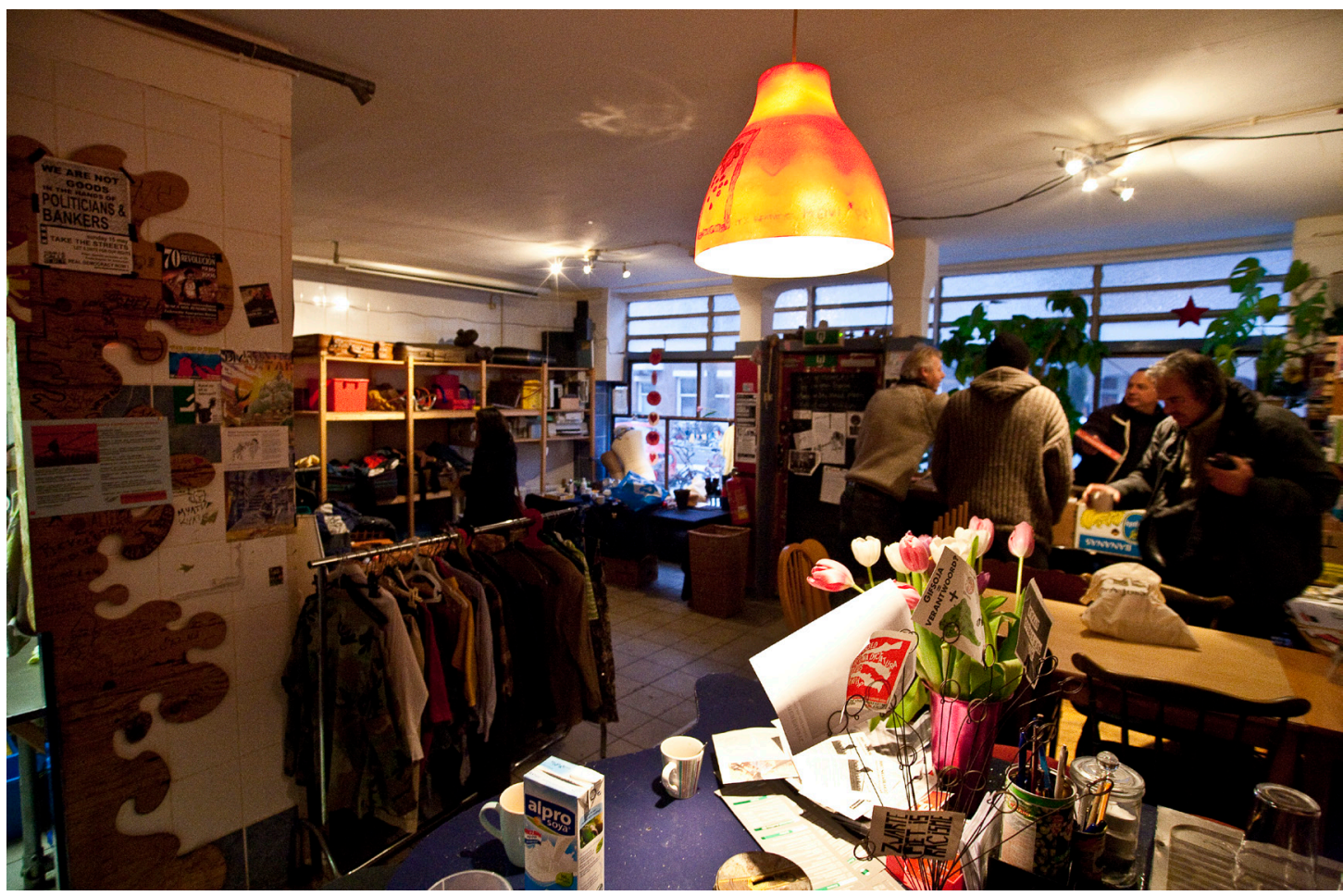

Photo from site Weggeefwinkel in Joe's Garage site, available at:

https://joesgarage.nl/weggeefwinkel

In Joe's Garage website, they explain their goal with their weggeefwinkel with this words:

So a giveaway shop is a place where nothing is for sale and everything is free. A giveaway shop is not a rubbish tip, but a place where you can drop off what is too good to throw away and where you can take what you need with you. In a giveaway shop there is always enough for everyone's needs, but not enough for everyone's eagerness. (Joe's Garage, 2020)

In September 2020, due to Corona crisis, they plan to open up the "wegeefwinkel" in the street, the image in their site invites people to join them for giving and getting free clothes. 


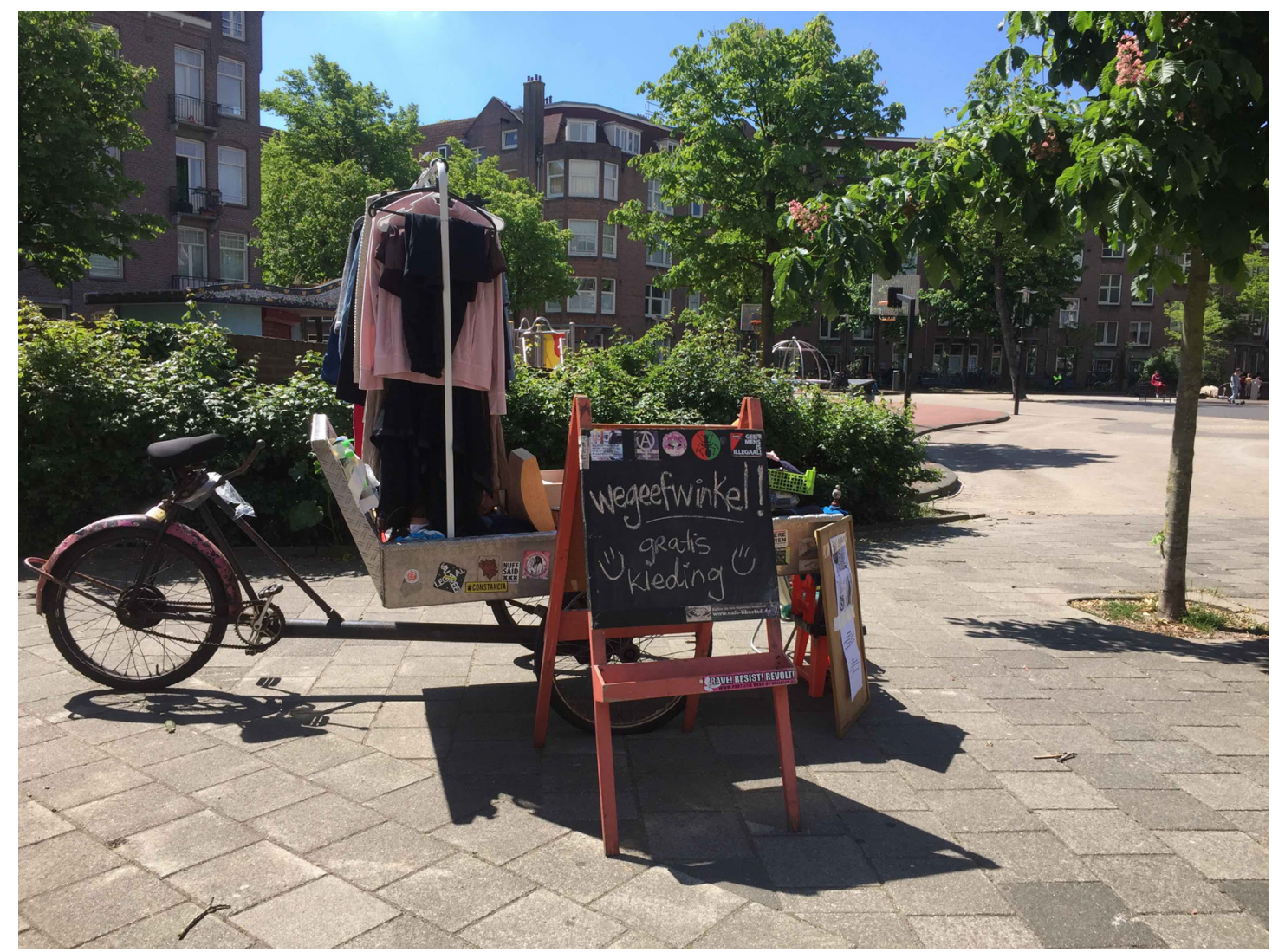

Image available online at: https://radar.squat.net/en/event/amsterdam/joes-garage/2020$\underline{09-29 / \text { wegeefwinkel-op-straat-freeshop-street?language }=\text { en }}$

Reuse is also called Rehome, to give a second home for clothes and objects. It is also a way to offer objects and clothes for people to Repurpose them as well. It became fashionable to use a second-hand pan to create a lamp or an old rain boot to create a flower pots. "It helps people to save money and to help the planet", according to Joe's Garage organisers.

\section{4) Recycle}

\section{Precious Plastic}

One experience of innovation originated in The Netherlands became an international movement: Precious Plastic. Created in 2014, it expanded so much that the creator of this network of small entrepreneurship proposed an ambitious name for it: Plastic Precious Universe. It promotes to treat plastic as precious material, so instead of throwing it in you waste bin, they ask you to separate it, take off the label and to deliver in a "collection point". From this collection point in the community, the plastic can be 
processed. This will happen in other small businesses located in the area. Some will develop the machines that have their industrial design available in open source technical manuals available in the site of Precious Plastic. They use a Creative Commons Attribution - Sharealike International 4.0 ${ }^{13}$.

Some businesses develop and build this kind of machines to shredder the plastic packaging, some other machines will be created for melting and baking and making tiles, bricks and utensils or objects from this recycled plastic. The innovation comes from the machines design and business model created initially by the creator of Precious Plastic, Dave Hakkens. He started it as part of his studies at the "Design Academy in Eindhoven". The machines used to shred and to melt the plastic were created and designed and made available, as written above, as "open source". He shared his design and results in 2013 in his graduation exhibition. One year later, three people replicated the machines. So, in 2015, Hakkens and some other colleagues developed a second version of the machines and kept posting about what they were trying to develop in the internet. They developed a kind of design for creating a recycling unit inside of old ship containers. Then, via internet, they created a community of recyclers.

Now, the business model evolved and in their homepage you can find many tutorial videos and manuals to start your own business to recycle plastic. They also developed a chat/debate community using "Discord “, a web platform where people can interact and where members from Precious Plastic try to help each other with tips and information. In the URL http:www.preciousplastic.com you can also find information about how to create a small business and how to organize and to join the network. When I started studying recycling and solid residue management in 2016, Precious Plastic was still a small innovation project. Now, just four years later, it became a world community and it is present in many countries like Brazil, India, Australia and in many European countries. They inform in their homepage: "Our online community counts on over 80.000 users working together and collaborating to find answer and solutions to tackle plastic pollution.” (Precious Plastic, 2020), Precious Plastic entrepreneurs use collected, shredded pellets of plastic to melt and, with machines they built themselves, create new

13 This license means you are free to share and to adapt but needs to take into account the terms of attribution (give appropriate credit, provide a link to the license and to indicate if changes were made and then you sharealike, which means that you need to distribute your contributions under the same license as the original. To learn more about this creative commons license, check: https://creativecommons.org/licenses/by-sa/4.0/ 
objects like, for example, chairs, decoration objects like plaits and lamps, light switchers, skates boards. It is a small and medium scale recycling movement.

\section{5) Recreate}

\section{Precious Plastic (again)}

The case of Recreate is also related to Precious Plastic. They started proposing designs and ideas to recreated using plastic. So, they now have developed machines and moulds so that people can share their innovation experiences in developing recycling of second hand plastic to make pieces for chairs, for electric plugs and light switchers.

In the homepage, they explain what do they offer in what they call "starter kits": "packages with everything you need to kick off your recycling projects and tackle the plastic waste problem. Add lots of enthusiasm and you're ready to go". (Precious Plastic, 2020). There are many projects that are being suggested for the entrepreneurs that want to start something, such as creating beamers for construction, bricks and plastic sheets that can be used in decoration. They are becoming more and more professionalised and started offering also personal assistance and training. They set up workspaces in Kenya, Chile and Bangladesh, for example. Their moto in this new phase is "Taking you from zero to hero, the Precious Plastic way" (Precious Plastic, 2020). They present themselves as an "active ecosystem of resources, platforms, tools and people collaborating and recycling plastic worldwide" and they estimate there are 80,000 people involved in the Precious Plastic network in 2020.

The Precious Plastic Universe is now formed by people that identify themselves as "members" that can be of different types: 1) members, people that separate the plastic and bring to the collecting point, 2) workplaces (where plastic get transformed from waste into valuable materials or products and can be of five sorts: shredder, extrusion, sheet press, injection and mix); 3) machine shops that produce and build parts, moulds and entire machines for the workplaces; 4) community point are the ones that make the educational and communication work of networking and informing about the project and 5) collecting point where the plastic is gathered from neighbours, organisations and businesses that will be used by the shredder and other workplaces. They have been busy in trying to foresee a future without plastic, so there are people involved in projects that 
researches biodegradable alternatives to plastic and to experiment with pressing biomaterials to create plates, bowls and cups. It is called "Beyond Plastic".

\section{6) Repair}

\section{Repair Cafe}

"Repair is Radical", said to me a school teacher last year when I was interviewing him about his work as a volunteer repairer in a Café Repair in Amsterdam in 2019. This communitarian innovation experiment started in 2007 by the initiative of Martine Postma. She was interested in developing locally sustainable projects, so in October 2009 she organised in Amsterdam-West the first Repair Café. Within two years, she created the Repair Café Internaional Foundation to offer support for voluntaries that wanted to offer repair help to people to try to amend their own stuff. It started mainly for repairing of electronic equipments, but it has also now workshops where people can learn how to repair their own clothes.

It works very simple. Basically it is a neighbourhood meeting that take place in a certain date where people can volunteer to repair other people's equipments, objects and/or clothes. The internet site define cafe repair like this:

Repair Cafés are free accessible meetings that revolve around repairing (together). At the location where the Repair Café is held, tools and materials are available to carry out all possible repairs. On clothing, furniture, electrical appliances, bicycles, toys etc. Expert volunteers are also present, with repair knowledge and skills in all kinds of areas. (Café Repair, 2020)

So, people from a certain neighbourhood bring with them broken items and some other people volunteer as experts. It is a local initiative that became popular in The Netherlands. Many of the visitors are older people that have learned to repair with their parents. In my fieldwork in Amsterdam, I met some retired men that enjoyed a lot to offer their expertise and help in the Café Repair as a way to socialise with other people as well. They came to help but also to drink a cup of coffee and tea with their neighbours, as the internet site advertises. Like Precious Plastic, this experiment is also a kind of "creative common" license, the site tries to stimulate people to volunteer and 
to start a Café Repair in their own area. It is an example of "social technology or “tecnologia social", as Pozzebon (2015) presents it.

In the Cafe Repair, they also advocate for products to last longer. Postma also in her interviews calls the attention for products that can be repaired instead of the ones that are designed in a way that they can just be thrown away when something is broken. Postma explained that The Café Repair's goal is to promote public knowledge about products and that the consumers feel responsible for trying to repair their products, as part of a sustainable behaviour concerning consume of equipments. Postma is shown in the document of the government of The Netherlands as an example of how products need to be design easy to repair" (The Netherlands 2016: 16).

The Café Repair social innovation was spread and now there are several cafes organised in other countries such as Belgium, Germany, France, United Kingdom and the United States of America. Recently there were some initiatives starting in India and Japan as well. Mainly their goal is to bring awareness that equipments can be designed in a way that they can be repaired. As my anthropologist colleague from the Vrije Universtiteit Freek Colombijn told me, he heard from a volunteer in a Café Repair that his main concern was that the equipments were built in the factories in a way nowadays that made it very difficult to open them without damaging the plastic body of the product. I have heard almost the same remark from an old experienced repairer in De Pijp in Amsterdam. He told me that when he was young all equipments could be opened with a screwdriver and now he could hardly open easily an electric equipment without damaging its case. "They mainly are glued, so it is almost impossible to open an electric utensil up without destroying it", he said to me.

In the Amsterdam neighbourhood De Pijp, I carried out fieldwork about community initiatives to keep the neighbourhood clean and tidy. Together with MSc candidate Andel Ottevangers, we went to communitarian meetings in the Wijkcentrum De Pijp, to research about a project called "Schoon de Pijp" (Clean De Pijp). We looked for urban compost solutions and the only one we found was an organic compost organised in the Sarphati Park, where some neighbours brought their organic solid residue to be used in a organic compost to supply compost and biofertiliser for the park. I was very glad when I finally found out another initiative dealing with the urban composting. I will present it as the last R from the 7Rs, that is to "Rot", which means solid residue composting. 


\section{7) Rot}

\section{Wormenhotels in Dutch, Worms' Hotel in English}

In the neighbourhood De Pijp, it was created the first "Wormenhotel", an urban organic compost with worms in 2014. Designed and built by Rowin Snijders, it was installed in the Franshaalstraat, in De Pijp. This initiative was copied and adapted and now the municipality of Amsterdam had reproduced it by giving subsidies for neighbours who want to participate in this urban area composting effort. In The Netherlands, there is an acronym for this kind of solid residue: GFT residue, the letters stand for G (in Dutch "groenten", vegetables in English), F (fruits) and T for "tuin"that means rests of garden like leaves and tree branches. The "wormenhotels" are a kind of cupboard where there are boxes with living worms and other microorganisms that will do the work of composting organic waste. There are now almost 100 "wormenhotels" in the city of Amsterdam and it became an organic rotting solution for urban inhabitants to separate and to give a proper destination to their GF (vegetables and fruit) residue.

Snijders became more professionalised, he has a small initiative called Le Compostier where he sells compost solutions for restaurants and other companies or institutions. The innovation was copied and spread around in many neighbourhoods of Amsterdam. There are many cities who copied the initiative as well. A study was published in 2019 by the municipality of Amsterdam comparing the initiatives of different areas. The final report considered that Amsterdam had "gold in its hands" with such an initiative. In the final report, it was concluded that:

The worm hotels have positive social effects in several areas:

1. The worms' hotels draw attention in a positive way to circular waste flows and a sustainable living.

2. Participants of worms' hotels feel more social cohesion in their neighbourhood.

3. The worms' hotels contribute to local employment, also for people who are disadvantaged up to the labour market.

4. With the worms' hotels, the City of Amsterdam can (re)gain confidence with regard to the separation of GF-separated. 
The report suggests that the municipality of Amsterdam should keep on investing and offering subsidie for the "wormenhotels". Nowadays, there are several different models available in IJburg and this neighbourhood developed one design that costed significantly less than the ones from other city areas. "It was because people volunteer to construct them", told me Janneke Verwey that created "wormenhotels" in the IJburg with the dedication of many volunteers. She started creating them in 2017. From July 2020, the IJburg "wormenhotels" started to be managed and maintained under the responsibility of the municipality of Amsterdam ${ }^{14}$.

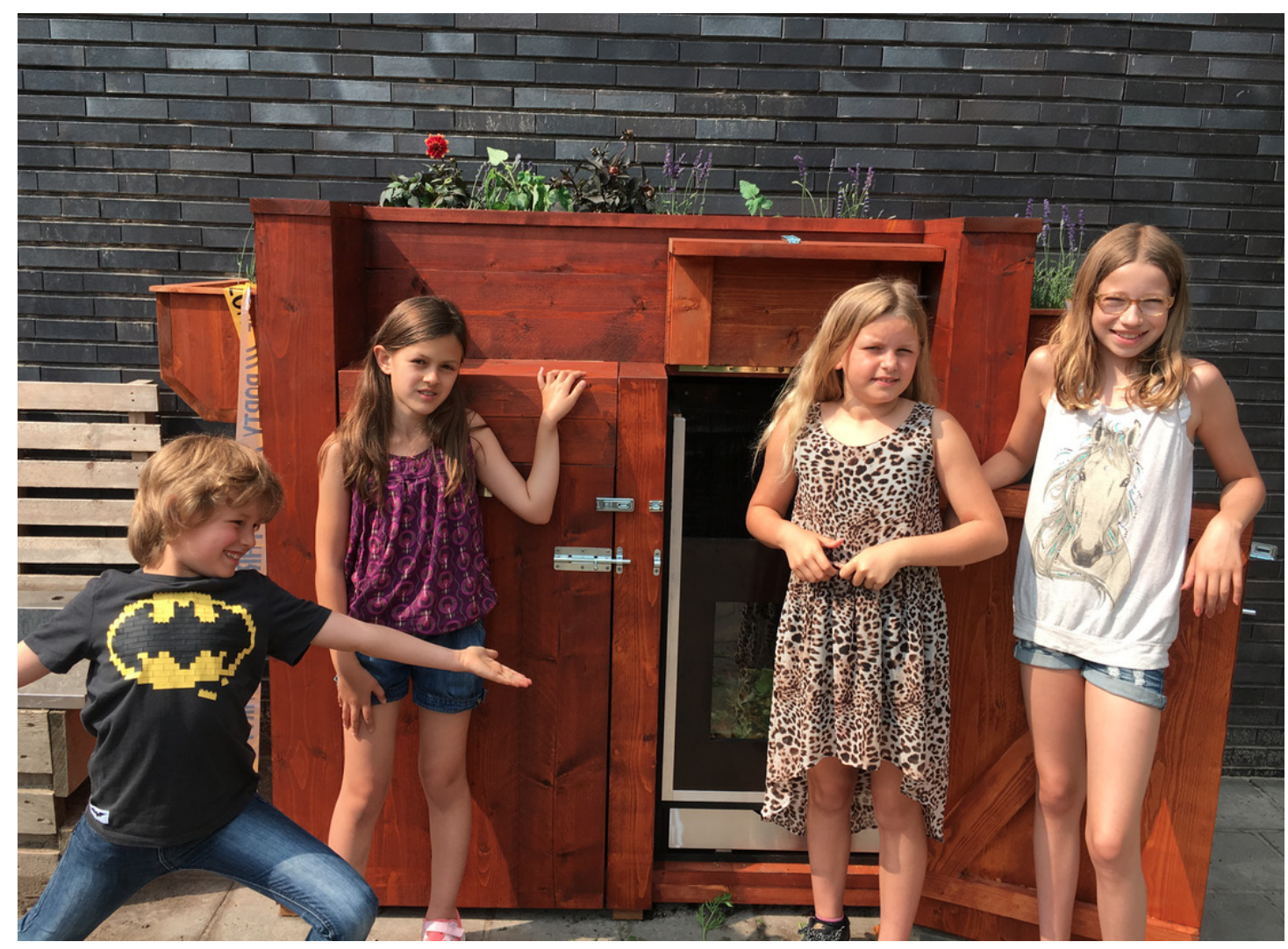

Photo by Janneke Verwey show children in IJburg neighbourhood inaugurating one new wormenhotel. Available at:

https://halloIJburg.nl/project/4884/nieuwe-wormenhotels-opstarten

\footnotetext{
14 To read more on wormenhotels, check https://www.cocasa.com/compost and https://wormenhotel.nl/verhalen/
} 


\title{
Utopia and imagination
}

Finally to end this paper, I would like to call the attention to some inspiration I got from the philosopher Isabelle Stengers when she states that we are "intruders" in Gaia", as our planet was named after the mythological Greek goddess:

\begin{abstract}
What I am naming Gaia was in effect baptized thus by James Lovelock and Lynn Margulis at the start of the 1970s. They drew their lessons from research that contributed to bringing to light the dense set of relations that scientific disciplines were in the habit of dealing with separately - living things, oceans, the atmosphere, climate, more or less fertile soils. To give a name - Gaia - to this assemblage of relations was to insist on two consequences of what could be learned from this new perspective. That on which we depend, and which has so often been defined as the "given," the globally stable context of our histories and our calculations, is the product of a history of coevolution, the first artisans and real, continuing authors of which were the innumerable populations of microorganisms. (Stengers, 2015)
\end{abstract}

In some of her lectures, Stengers criticises that the universities' knowledge production became increasingly part of the "war games of the corporate world" and we, academic people, are all part of a competitive economic regime.

As I wrote in the beginning of this paper, when I started researching about circular economy, I thought that the European Union documents would be driven by sustainable ecological mission and devoted to the continuity of a sustainable life in the planet. I found out that the European documents were more worried about developing an economy goal and that in fact the documents did not bring information about ecology and sustainable futures. Then, when I left the documents and started researching for people's solutions, more hands-on approach I started to feel again that there were possible ecological outcomes out of my research. After four years researching innovative projects in The Netherlands, I became again optimistic. Because at least I found out people that created and developed innovations and initiatives that help to place utopia and imagination for a better future in the agenda of my academic and anthropological research.

Stengers in the last paragraphs of her book "The Intrusion of Gaia" wrote as well:

Learning to compose will need many names, not a global one, the voices of many peoples, knowledges, and earthly practices. It belongs to a process of multifold creation, the terrible difficulty of which it would be foolish and dangerous to underestimate but which it would be suicidal to think of as impossible. (Stengers, 2015) 
I hope this paper contributes to bring awareness to some local knowledge and local processes of creation and of innovation that are engaged in producing life. Their creativity and their innovations are responses to create community life possible for humans in Gaia, our planet. The 7Rs practices presented in this paper show how sustainable and ecological innovations can shine some light of utopia for our engagement and for our imagination for possible futures.

\section{REFERENCES}

BRANDER, Sabine. 2020. Afval in de stad: het 100-100-100 initiatief in Amstelveen. Culturele antropologie en ontwikkelingssociologie Bachelor scriptie, Vrije Universiteit Amsterdam. 14p.

DAGNINO, R., BRANDÃO, F \& NOVAES, H. T. Sobre o marco analítico-conceitual da Tecnologia Social. In: A. Lassance Jr. et alli. Tecnologia Social: uma estratégia para o desenvolvimento. Rio de Janeiro: Fundação Banco do Brasil. Pp 15-64. 2004.

DUTCH NEWS. Mind your Ps: Amsterdam installs plant pot street urinals to improve toilet manners. DutchNews.nl Aug 14. 2020. Available at: https://www.dutchnews.n1/news/2020/08/mind-your-ps-amsterdam-installs-plant-pot-streeturinals-to-improve-toilet-behaviour/

ERIKSEN M, Lebreton LCM, Carson HS, Thiel M, Moore CJ, Borerro JC, et al. Plastic Pollution in the World's Oceans: More than 5 Trillion Plastic Pieces Weighing over 250,000 Tons Afloat at Sea. PLoS ONE 9(12): e111913. 2014. https://doi.org/10.1371/journal.pone.0111913

EUROPEAN COMMISSION. Communication from the Commission to the European Parliament, the Council, the European Economic and Social Committee and the Committee of the Regions. A new Circular Economy Plan. 2020. Available at: https://eurlex.europa.eu/legal-content/EN/TXT/?qid=1583933814386\&uri=COM:2020:98:FIN

EUROPEAN COMMISSION. Circular Economy: closing the loop. An ambitious EU Circular Economy Package. 2015. Available at:

https://ec.europa.eu/commission/sites/beta-political/files/circular-economy-factsheetgeneral_en.pdf

HETEMÄKI, L., HANEWINKEL, M., Muys, B., OLLIKAINEN, M., PALAHÍ, M. and TRASOBARES, A. Leading the way to a European circular bioeconomy strategy. From Science to Policy 5. European Forest Institute. 2017.

Available at:

https:/efi.int/sites/default/files/files/publication-bank/2018/efi_fstp 5 2017.pdf

HOFMANN, Florian. 2019. Circular business models: Business approach as driver or obstructer of sustainability transitions? Journal of Cleaner Production 224, Pp. $361-374$. 
IAMSTERDAM. Amsterdam's innovative spirit. 2020. Available at: https://www.iamsterdam.com/en/business/news-and-insights/capital-ofinnovation/innovative-spirit

JACOBI, Pedro Roberto; BESEN, Gina Rizpah. 2011. Gestão de resíduos sólidos em São Paulo: desafios da sustentabilidade. Estud. av., São Paulo, v. 25, n. 71, p. 135-158, Apr. Available from http:/www.scielo.br/scielo.php?script=sci arttext\&pid=S010340142011000100010\&lng=e $\underline{\text { n\&nrm}=i s o}$ access on $04 \quad$ Oct. 2018. $\quad \underline{\text { http://dx.doi.org/10.1590/S0103- }}$ 40142011000100010

KAMMINGA-NTI Mensah, Margriet. Hoe het anti plastic-sentiment greenwashing in stand houdt. Culturele antropologie en ontwikkelingssociologie Bachelor scriptie, Vrije Universiteit Amsterdam. 25p. 2020.

LIBORIAN, Max. Redefining pollution and action: The matter of plastics. Journal of Material Culture. Pp 1-24. 2015. Available at:

https://maxliboiron.files.wordpress.com/2013/08/liboiron-plastic-pollution-journal-ofmaterial-culture-2015.pdf

McDONOUGH, William \& BRAUNGART, Michael. 2002. Cradle to Cradle: Remaking the Way We Make Things. New York: North Point Press.

POZZEBON, Marlei. 2015. Tecnologia Social: A South American View of the Regulatory Relationship between Technology and Society. In: de Vaujany FX., Mitev N., Lanzara G.F., Mukherjee A. (eds) Materiality, Rules and Regulation. Technology, Work and Globalization. Palgrave Macmillan, London.

Available at: https://doi.org/10.1057/97811375

PURVIS, Ben, MAO, Young \& ROBINSON, Darren. Three pillars of sustainability: in search of conceptual origins. Sustainability Science, 14, Pp 681-695. 2019.

Available at: $\underline{\text { https://doi.org/10.1007/s11625-018-0627-5 }}$

RESEARCH GROUP OBSOLESCENCE. 2019. From Take-Make-Dispose to a Circular Society: Introduction of a new vision in six propositions. Technische University Berlin. Available at: https://challengeobsolescence.info/wp-content/uploads/2019/06/190628 CSBroschüre final SCREEN-1.pdf

STEGMAN, Paul; LONDON, Marc \& JUNGINGER, Martin. 2020. The circular bioeconomy: Its elements and role in European bioeconomy clusters. Resources, Conservation \& Recycling: X, v. 6, May. https://doi.org/10.1016/j.rcrx.2019.100029

STENGERS, Isabelle. 2015. In Catastrophic Times: Resisting the Coming Barbarism. Translated by Andrew Goffey. Open Access book available at:

http://modesofexistence.org/isabelle-stengers-the-intrusion-of-gaia/

THE NETHERLANDS. 2016. A Circular Economy in The Netherlands by 2050: government-wide programme for a Circular Economy. The Ministry of Infrastructure and the Environment and the Ministry of Economic Affairs, also on behalf of the Ministry of Foreign Affairs and the Ministry of the Interior and Kingdom Relations. Available at: 
https://www.government.nl/documents/policy-notes/2016/09/14/a-circular-economy-in-thenetherlands-by-2050

VAN FRANEKER, Jan \& KÜHN, Susanne. 2019. Fulmar Litter Eco monitoring in The Netherlands - update 2018. Wageningen Martine Research Report C077/19 \& RWS Centrale Informatievoorziening BM 19.16. Den Helder 60pp.

VAN FRANEKER, Jan \& KÜHN, Susanne. 2020. Informatie document dat naar Britse vrijwilligers in het stormvogelproject is gestuurd. Available at: https://www.wur.nl/upload_mm/a/4/e/c0cd5590-5909-43bc-88ad-

f274b342e14b_Findersinformation_UK_3rdBatch2019.pdf

\section{Internet sites:}

100-100-100 Social Experiment

https://www.100-100-100.nl

Cafe Repair

https://repaircafe.org/over/

Green Living Lab

https://greenlivinglab.org

Le Compostier

http://compostier.blogspot.com

Plastic Soup Foundation

https://www.plasticsoupfoundation.org

Precious Plastic

https://preciousplastic.com

Weggeefwinkel Joe's Garage

https://joesgarage.nl/weggeefwinkel

Wormenhotels

https://wormenhotel.nl/verhalen/

https://www.cocasa.com/compost

https://wormenhotel.nl/soort/buurt/lecompostier/

https://wormenhotel.nl/soort/buurt/lecompostier/

Recebido: $02 / 10 / 2020$

Aprovado: 08/12/2020 